\title{
Effects of Heifer Calving Date on Longevity and Lifetime Productivity in Western Canada
}

\author{
Daalkhaijav Damiran ${ }^{1,2}$, Kathy Larson ${ }^{1,2}$, Leah Pearce ${ }^{1}$, Nathan Erickson ${ }^{3} \&$ H. A. (Bart) Lardner ${ }^{1,2}$ \\ ${ }^{1}$ Western Beef Development Centre, Humboldt, Saskatchewan, Canada \\ ${ }^{2}$ Department of Animal and Poultry Sciences, University of Saskatchewan, 51 Campus Drive, Saskatoon, SK \\ S7N 5A8, Canada \\ ${ }^{3}$ Department of Large Animal Clinical Sciences, University of Saskatchewan, Saskatoon, SK, Canada, S7N 5A8, \\ Canada
}

Correspondence: Daalkhaijav Damiran, Department of Animal and Poultry Sciences, University of Saskatchewan, 51 Campus Drive, Saskatoon, SK S7N 5A8, Canada. Tel: 306-966-4173. E-mail: daal.damiran@usask.ca

Received: July 4, 2018 Accepted: July 25, 2018 Online Published: July 30, 2018

doi:10.5539/sar.v7n4p11 URL: https://doi.org/10.5539/sar.v7n4p11

\begin{abstract}
The objective of this study is to determine the effect of calving early as a heifer on lifetime production in western Canada. This study evaluated the longevity and life time production data on 211 individual heifers (data gathered for 16 years) at the Western Beef Development Centre (WBDC), Saskatchewan. Heifers were classified as calving in the first (period 1; $\mathrm{n}=87$ ), second (period 2; $\mathrm{n}=66$ ), or third (period 3; $\mathrm{n}=58$ ) 21-day period of the calving season. For each subsequent calf born to the cow, calving period was reassigned in the same manner. The current study showed that the average life time number of calves weaned for heifers that calved in the 1st, 2nd, and 3rd 21-day period was $5.4 \pm 0.32,4.5 \pm 0.37$, and $4.2 \pm 0.39$, respectively. Retaining percentage rate of period 1 cows was 4.3-17.8 and 2.1-19.1\% units greater than those of period 2 and period 3 cows, respectively. Period 1 heifers had the greatest life time produced total cumulative weaning weight $(p<0.01)$ value of 1157 $\mathrm{kg} / \mathrm{cow}$, followed by period 2 and period 3 heifers, 947 and $841 \mathrm{~kg} / \mathrm{cow}$, respectively. Period 1 cows generated an additional $\$ 718$ to $\$ 1077$ in weaned calf revenues over their lifetime. This study suggested that, in western Canada, heifers that calved earlier had greater pregnancy rates, remained in the herd longer, and produced one more calf in their lifetime than those that calved in the later periods.
\end{abstract}

Keywords: beef, fertility, heifer, calving distribution, lifetime production, reproductive longevity

\section{Introduction}

The sustainability and profitability of a cow-calf operation is dependent on the longevity of each breeding female and the production of a live calf every year. If a heifer calves earlier in the calving season (first 21-day period), they have more time to heal and resume cycling before the next breeding season commences in order to maintain a $365 \mathrm{~d}$ calving interval. A limited number of reports are available regarding the relationship between cow calving time as a heifer and subsequent longevity and production as cows (Burris \& Priode, 1958; Wiltbank, 1970; Lesmeister, Burfening, \& Blackwell, 1973; Sprott, 2000; Funston, Musgrave, Meyer, \& Larson, 2012; Cushman, Kill, Funston, Mousel, \& Perry, 2013). Burris and Priode (1958) showed that cows calving late in one year tended to continue that trend, calving late in the following year or coming up open. Similarly, Wiltbank (1970) stressed the importance of heifers conceiving early in their first breeding in order to have good lifetime production performance and was one of the first to suggest calving heifers earlier than the rest of the herd given their longer post-partum interval (80-100 days vs. 50-60 days for cows). Lesmeister et al. (1973) demonstrated the importance of breeding heifers to calve early to maintain calving period throughout their time in the herd and that heifers that calve early will produce more kilograms of calf in their lifetime than heifers that calve later in their first calving. Sprott (2000) analyzed calving records from five Texan herds to show that average lifetime calf weight is highest for females whose first calf was born in the first $21 \mathrm{~d}$ of the calving season. Similarly, Funston et al. (2012) reviewed thirteen years of production records from Gudmundsen Sandhills Laboratory, Nebraska and found calving period influenced a heifer's herd performance with heifers that were born in the first calving period having higher first conception rate, percentage calving in first $21 \mathrm{~d}$, first calf weaning weight and 
second conception rate than heifers born in the second or third calving period. Furthermore, Cushman et al. (2013) showed that having heifers calve early in their first calving resulted in increased herd retention and the additional kilograms of calf weaned by an early-calving heifer equated to the production of an extra calf during her lifetime. To our knowledge, no publications could be found on the influence of calving early as heifer on future and lifetime performance in western Canada. The objective of this study is to determine the effects of calving early as heifer on her lifetime reproductive performance and productivity using a western Canadian data set.

\section{Materials and Methods}

\subsection{Source of Data}

Data were aggregated into a database from the Western Beef Development Centre's (WBDC; Saskatchewan) beef cattle research herd production records. The University of Saskatchewan Animal Research Ethics Board (Protocol No. 20090107) approved the procedures and facilities used in this experiment and animals were cared for according to the guidelines of the Canadian Council of Animal Care (2009). The WBDC follows typical management practices of western Canada for beef heifer development, cow breeding and nutrition, as described elsewhere (Krause et al., 2013; Lardner, Damiran, Hendrick, Larson, \& Funston, 2014; Damiran, Lardner, Larson, \& McKinnon, 2016; Damiran, Penner, Larson, \& Lardner, 2018; McMillan et al., 2018). Data for the spring calving herd collected between 2001 and 2017 were used for this study. The breeding season at WBDC began approximately June 20 each year and lasted for $\sim 65$ days. Weaning occurred each year in late October (at $\sim 160 \mathrm{~d}$ of age). Data were trimmed to remove heifers that produced a twin at any point during their life. Females sold or culled for non-breeding reasons (e.g., mothering, milk, conformation, temperament) were removed from the data set. Heifers were also eliminated from the data set if proper assignment to an initial calving group was not possible due to abortion, or birth of an abnormal or premature calf. The final data set for this study consisted of 211 Black Angus and Angus crossbred heifers born from 1999 to 2008.

Each female's calving date was assigned a number (Julian date) corresponding with calving span. Postpartum recovery period was estimated by subtracting $282 \mathrm{~d}$ (average gestation length) from the calving interval (Damiran et al., 2016). Two-year old first-calf heifers were assigned to one of three 21-day calving periods based on the date their first calf was born. Each subsequent calf born to the cow was also assigned to a calving group (or period), but for analysis purposes the female remained in the group number assigned for her first parturition. For example, a cow that calved in Period 2 as a heifer but then had her next three calves in Period 3, was analyzed as a Period 2 female. Average lifetime production was calculated as the mean production of all calves whose dams were classified in a particular calving group as heifers. Weaned calf revenue was calculated, $\$ /$ cow $=$ Calf cumulative weaning BW, $\mathrm{kg} / \mathrm{cow} \times \mathrm{WCP}, \$ / \mathrm{kg}$, where $\mathrm{WCP}=$ weaned $249.4 \mathrm{~kg}(550 \mathrm{lb})$ calf prices, over the last nine years (2008-2017) in Saskatchewan, Canada, have averaged \$3.68/kg (CANFAX, 2017). All dollar values are in Canadian dollars.

\subsection{Statistical Analysis}

Data (heifer age of birth, Julian day of calving, calf birth weights, calving interval, calf weaning age and weight, adjusted 205-d weaning weight of all calves that survived until weaning, and longevity of cows) were analyzed using the MIXED procedure of SAS 9.2 (SAS, 2003). The model used for the analysis was: $Y_{i j}=\mu+T_{i}+e_{i j}$; where $Y_{i j}$ was an observation of the dependent variable ${ }_{i j} ; \mu$ was the population mean for the variable; $T_{i}$ was the fixed effect of the contemporary heifer calving group (Period 1, Period 2, and Period 3); and eij was the random error associated with the observation ij. Heifer was considered an experimental unit. For all statistical analyses, significance was declared at $p<0.05$.

\section{Results and Discussions}

\subsection{Cow Retention and Longevity}

As indicated previously, in the current study, cows were culled or sold from the herd if they failed to be become pregnant (e.g., open). Figure 1 depicts percentages of cows remaining in the herd over time out to 9th calving based on retention data. Retaining percentage of period 1 cows was $6.5-18.3$ and 2.9-24.1\% units greater than those of period 2 and period 3 cows, respectively. Thus, heifers that calve later at their first calving fail to remain in the herd as long as heifers that calve earlier (first 21 days) at their first calving. The results of the current study agree with the previous findings (Cushman et al., 2013) in that having heifers calve early in their first calving would increase their retention in the herd. 


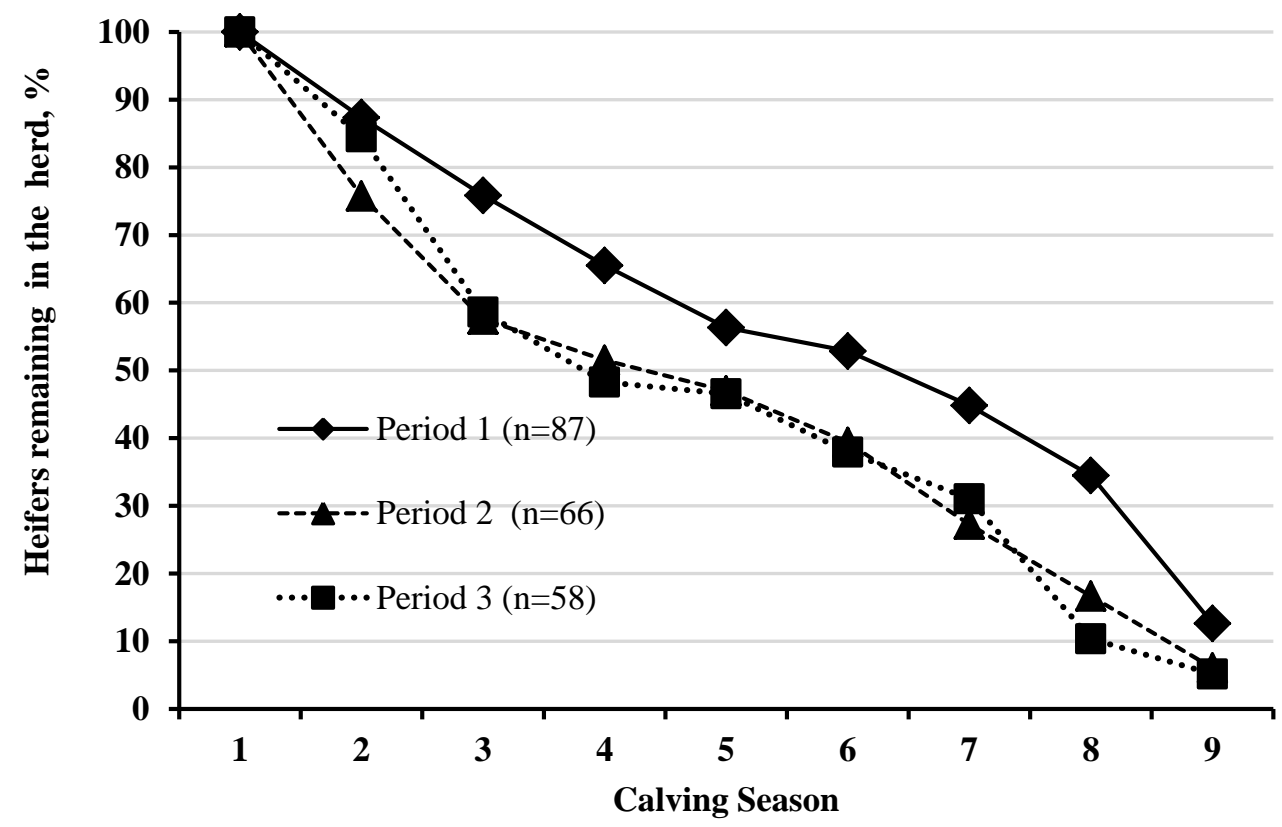

Figure 1. Analysis of the influence of calving period on herd survival from Western Beef Development Centre, Saskatchewan

Note. Results from Angus and Angus crossbred heifers $(\mathrm{n}=211)$. Period $1=$ calved in the first 21 days, $-2=$ calved in the second 21 days, $-3=$ calved in the third 21 days and after as heifer.

The longevity of a beef female is important to the sustainability and profitability of any beef operation (Cushman et al., 2013). Increasing longevity by improving retention of females can increase herd size. Figure 2 presents influence of calving period on beef cow average longevity from WBDC. In the current study, heifers that had their first calf during the first 21-day period of the calving season had increased $(p<0.05)$ longevity compared to heifers that calved in the second and third 21-day periods $(7.2 \pm 0.3,6.5 \pm 0.4$, and $6.2 \pm 0.4 \mathrm{yr}$ for period 1 , period 2 , and period 3 , respectively).

However, no difference $(p>0.05)$ was observed between period 2 and period 3 groups in longevity. The reason for the obtained results on cow retention time and longevity can be explained as Bridges (2013) noted, if a heifer conceives late and subsequently calves late, she has less time from calving until the start of the subsequent breeding season, so she is more likely to be anestrus, or not having estrous cycle, at the start of the breeding season and will likely conceive late again in the second breeding season; this cycle continues to repeat until eventually she fails to conceive in a confined breeding period and is culled from the herd.

\subsection{Effect of Initial Calving Group on Cow Calving Performance}

Effect of first calving period on a beef cow's lifetime calving performance are presented in Table 1. Age of the heifer at first calving affected calving group $(p<0.01)$. Heifers classified as calving in the first calving period were on average $19 \mathrm{~d}$ younger than those in the second period and $48 \mathrm{~d}$ younger than those in the third period ( $p$ $<0.01$ ). Heifers need to calve by 24 mo. (730 day of age) of age to achieve maximum lifetime productivity (Patterson et al., 1992). In the current study, only period 1 heifers reached the mentioned benchmark. 


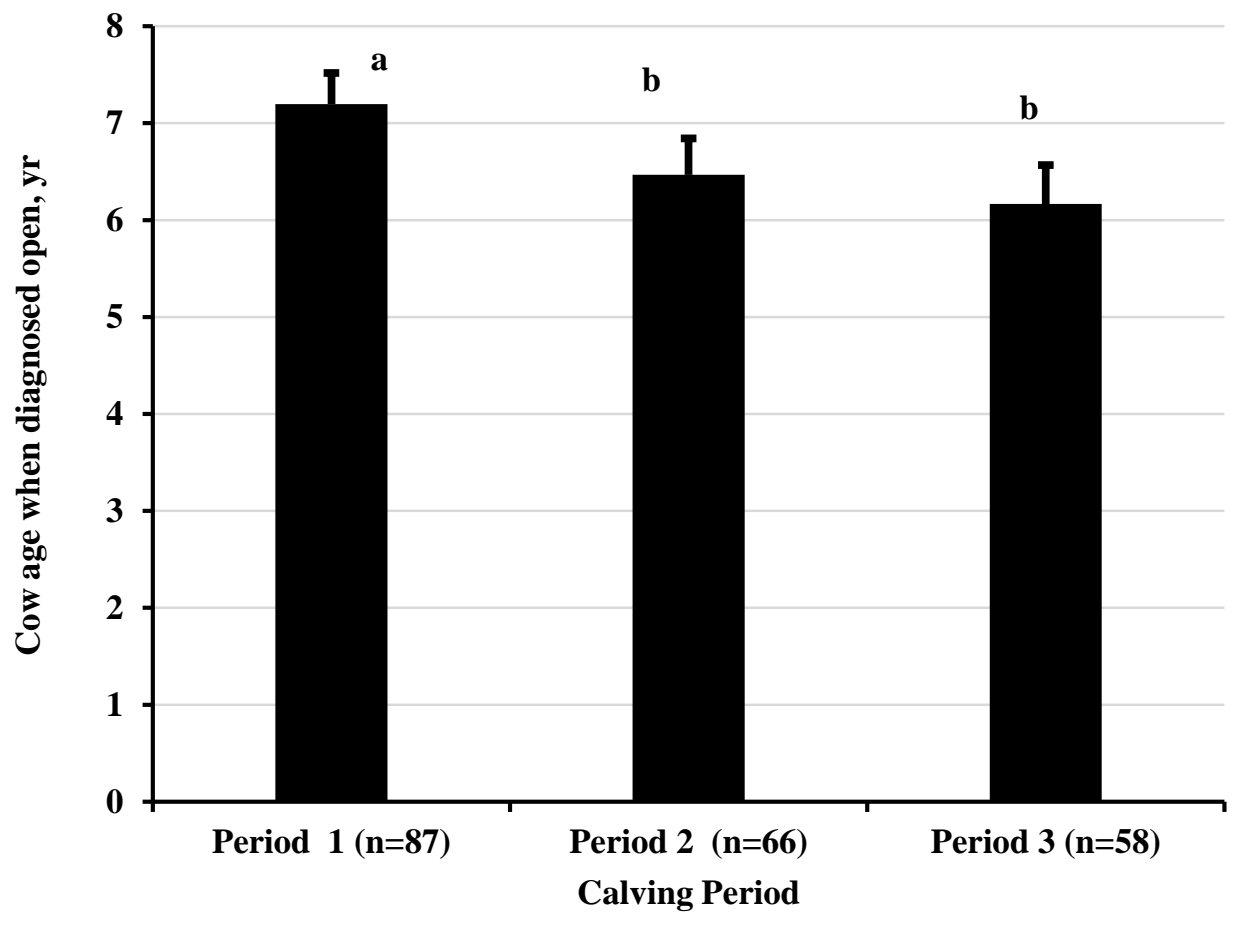

Figure 2. Effect of first calving period on life time in herd from Western Beef Development Centre, Saskatchewan Note. Period $1=$ calved in the first 21 days, $-2=$ calved between day $22-43,-3=$ calved after day 44 or later. ${ }^{\mathrm{a}, \mathrm{b}}$ Bars with different superscripts are different at $p<0.05$.

Table 1. Effect of first calving period on beef cow calving performance

\begin{tabular}{llllll}
\hline \multicolumn{7}{l}{ Calving period $^{1}$} & & & \\
\hline Item & Period 1 & Period 2 $^{2}$ & Period 3 & SEM $^{2}$ & $p$-value \\
\hline Initial heifer, n & 87 & 66 & 58 & & \\
Age at first calving, d & $731^{\mathrm{a}}$ & $751^{\mathrm{b}}$ & $778^{\mathrm{c}}$ & 3.6 & $<0.01$ \\
Calving interval, d & $376^{\mathrm{a}}$ & $372^{\mathrm{a}}$ & $358^{\mathrm{b}}$ & 1.8 & $<0.01$ \\
Postpartum interval, $^{3} \mathrm{~d}$ & $95^{\mathrm{a}}$ & $90^{\mathrm{a}}$ & $76^{\mathrm{b}}$ & 2.1 & $<0.01$ \\
Calf birth date, Julian day & $107^{\mathrm{b}}$ & $110^{\mathrm{b}}$ & $119^{\mathrm{a}}$ & 1.1 & $<0.01$ \\
Calf birth BW, kg & 40 & 40 & 40 & 0.5 & 0.80 \\
\hline
\end{tabular}

Note. ${ }^{1}$ Period $1=$ calved in the first 21 days, Period $2=$ calved between day 22 to 43 , Period $3=$ calved day 44 or later. ${ }^{2} \mathrm{SEM}$, pooled standard error of means. ${ }^{3}$ Estimated postpartum interval from calving to conception based on consecutive calving dates and assuming a $282-\mathrm{d}$ gestation length. ${ }^{\text {abc }}$ Means without a common superscript differ $(p \leq 0.05)$.

When production data for each year was pooled, cow groups were different from each other $(p<0.05)$ in calving date; and were $107( \pm 0.9), 110( \pm 1.1)$, and $119( \pm 1.3) \mathrm{d}$ for period 1 , period 2, and period 3 cows, respectively. This result indicated that the females that calved early as heifers tended to calve earlier throughout the remainder of their productive lives than the females that calved later in their first calving. The interval between postpartum estrus and beginning of pregnancy is the other component of the reproductive cycle. In the current study, period 1 (95 d) and period $2(90 \mathrm{~d})$ cows were similar $(p>0.05)$ in the length of estimated postpartum interval; both groups were greater $(p<0.01)$ than period 3 cows $(76 \mathrm{~d})$. A shorter calving interval was also observed for the Period 3 (late calving) females. These two results may seem counter intuitive at first, but can be explained by fall out with a defined $65 \mathrm{~d}$ breeding season. Only the most reproductive females from Period 3 remained in the study (the ones with short post partum intervals), while females in Period 1 and 2 had the leeway to not conceive in their first (and even second) cycle of the breeding season and still end up pregnant at the end of the breeding 
season. As cows ( 2 nd through 9th calving), estimated postpartum interval did not differ $(p>0.05$; data not shown) by heifer calving group and averaged $\sim 81 \mathrm{~d}$ (Period 3 group) to $87 \mathrm{~d}$ (Period 1 group). All 3 cow groups had similar $(p>0.05)$ calf birth BW.

\subsection{Effect of Initial Calving Group on Calf Weaning Performance and Lifetime Productivity}

It is typical for cow-calf operations are to wean all calves on a particular timeframe rather than on a weight-constant or age-constant basis; as such calves born early in the calving season are usually heavier at weaning than those born later. This tends to increase the total lifetime production of early-calving dams (Morrow $\&$ Brinks, 1968; Roberts et al., 1970). Therefore, calving date and actual weaning weight of calves are crucial for beef producers to measure. Effect of first calving period on a beef cow's lifetime calves weaning performance are presented in Table 2 . When lifetime productivity for each animal was pooled, calf actual average weaning weights were $15 \mathrm{~kg}$ heavier $(p<0.01)$ and average adjusted 205-d weaning weights were $9 \mathrm{~kg}$ heavier $(p<0.01)$ for the period 1 and 2 cows than period 3 cows. Calf gain to weaning (ADG) was lower $(p<0.05)$ for the calves from period 3 cows $(1.05 \mathrm{~kg} / \mathrm{d})$ than for the calves born to period $1(1.08 \mathrm{~kg} / \mathrm{d})$ and period 2 cows $(1.09 \mathrm{~kg} / \mathrm{d})$.

Table 2. Effect of first calving period on calf weaning performance and beef cow lifetime productivity

\begin{tabular}{llllll}
\hline & \multicolumn{3}{l}{ Calving period } & & \\
\cline { 2 - 4 } Item & Period 1 & Period 2 & Period 3 & SEM $^{2}$ & $p$-value \\
\hline Initial heifer, n & 87 & 66 & 58 & & \\
Total produced calves, n/cow & $5.4^{\mathrm{a}}$ & $4.5^{\mathrm{b}}$ & $4.2^{\mathrm{b}}$ & 0.36 & 0.03 \\
Calf age at weaning, Julian day & $167^{\mathrm{a}}$ & $164^{\mathrm{a}}$ & $149^{\mathrm{b}}$ & 2.0 & $<0.01$ \\
Calf weaning BW, kg & $218^{\mathrm{a}}$ & $217^{\mathrm{a}}$ & $202^{\mathrm{b}}$ & 2.5 & $<0.01$ \\
Pre-weaning ADG, kg/d & $1.1^{\mathrm{ab}}$ & $1.1^{\mathrm{a}}$ & $1.0^{\mathrm{b}}$ & 0.02 & 0.06 \\
Calf adjusted 205-d weaning BW, kg/cow & $264^{\mathrm{a}}$ & $264^{\mathrm{a}}$ & $255^{\mathrm{b}}$ & 2.1 & $<0.02$ \\
Calf cumulative weaning BW, kg/cow & $1157^{\mathrm{a}}$ & $947^{\mathrm{ab}}$ & $841^{\mathrm{b}}$ & 84.5 & 0.04 \\
Calf cumulative adjusted 205-d weaning BW, kg/cow & $1401^{\mathrm{a}}$ & $1156^{\mathrm{ab}}$ & $1064^{\mathrm{b}}$ & 97.4 & 0.03 \\
\hline
\end{tabular}

Note. ${ }^{1}$ Period $1=$ calved in the first 21 days, Period $2=$ calved between day 22 to 43 , Period $3=$ calved day 44 or later. ${ }^{2} \mathrm{SEM}$, pooled standard error of means. ${ }^{\text {abc }}$ Means without a common superscript differ $(p \leq 0.05)$.

Reproductive performance is one of the biggest factors affecting beef cow production efficiency and profitability. Reproduction has been estimated to be 3 to 9 times more influential on profitability than other production traits (Melton, 1995). Average lifetime calves weaned for WBDC cows that calved in the 1st, 2nd, and 3rd 21-day periods was $5.4 \pm 0.32,4.5 \pm 0.37$, and $4.2 \pm 0.39$ /cow, respectively. Due to combined effects of greater average number of calves weaned over lifetime and actual calf weaning weights, cows that had their first calf during the first 21-day period had $(p<0.01)$ greater total weight weaned $(1157.1 \pm 70.0 \mathrm{~kg})$ compared to heifers that calved in the second $(946.6 \pm 82.1 \mathrm{~kg})$ or $3 \mathrm{rd}(841.4 \pm 87.6 \mathrm{~kg}) 21$-d period (Table 2).

One of the most important findings of this study was females that calve early when they are heifers can produce more cumulative kilograms of weaned calf in their lifetime than females that calved later (after first 21 days) as heifers (i.e., cumulative kilograms of calf was $18.2 \%$ and $27.3 \%$ greater than that of period 2 and period 3 cows, respectively), which agrees with others' findings (Roberts, Spencer, LeFever, \& Wiltbank, 1970; Lesmeister et al., 1973).

\subsection{Effect of Initial Calving Group on Weaned Calves Revenue}

The Period 1 cows were either numerically or significantly greater than period $2(p>0.05)$ and period 3 cows $(p$ $<0.01$ ); generated an additional $\$ 773$ to $\$ 1160$ in weaned calf revenues over their lifetime (Figure 3). This represents a large financial advantage for cow-calf producers. The differences in average lifetime production between cow groups in the current study were likely associated with differences in total number of calves weaned over lifetime, but some differences were associated with calf weaning weight. In general, in western Canada, where cost of production has been measured at just under $\$ 962$ per cow wintered (Alberta Agriculture and Forestry, 2016) a heifer will need to wean a minimum of five consecutive calves to recoup her development costs (Kathy Larson, Western Beef Development Centre, Humboldt, SK, personal communication). This economic threshold of needing to wean five calves was only reached by the females that calved early as heifers. Thus the findings of this study demonstrate why it is so important for cow-calf producers to ensure that their replacement heifers conceive as early as possible in their first breeding exposure. 


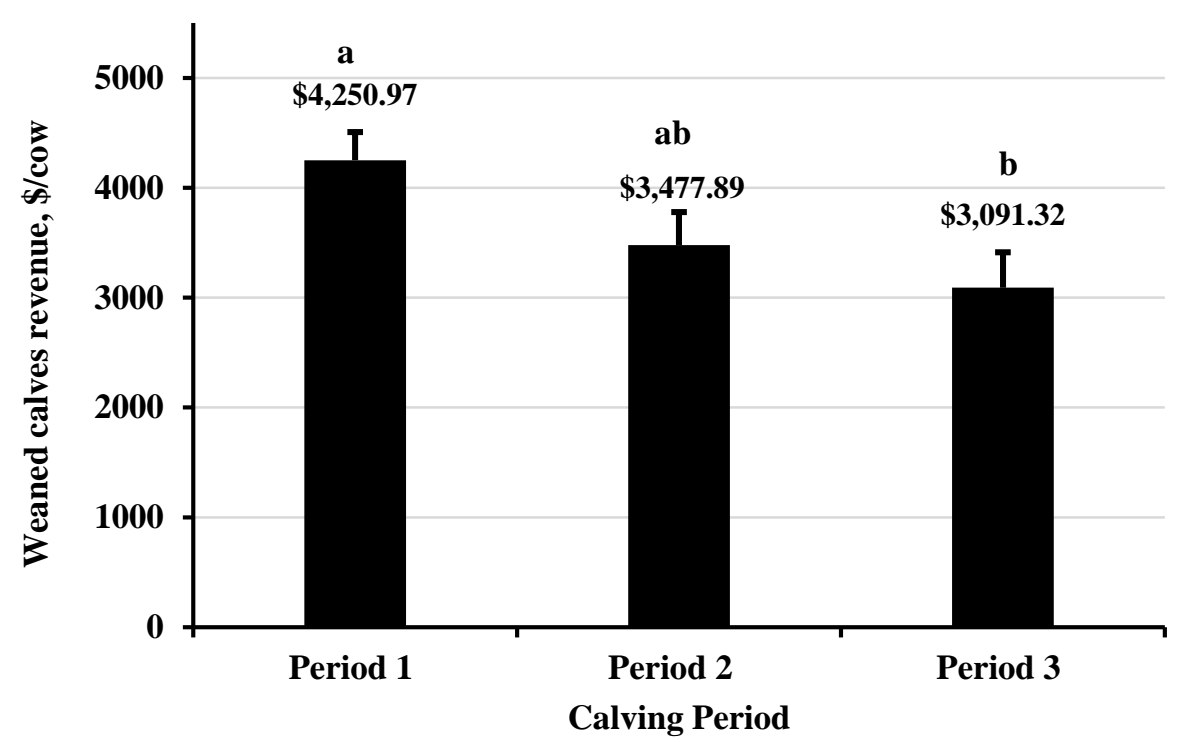

Figure 3. Influence of calving period on lifetime weaned calf revenue

Note. Revenue calculated as cumulative pounds weaned $\times$ estimated market value of $\$ 3.68$ per $\mathrm{kg}$ (which represents the 2008-2017 average price for 249.4 kg calves in Saskatchewan). ${ }^{\mathrm{a}, \mathrm{b}}$ Bars with different superscripts are significantly different $(p<0.05)$.

\section{Conclusions and Implications}

As evidenced by the findings of the current study, heifers that calved early in their first calving season had increased longevity (pregnancy rates) and weaned more calves, compared with heifers that calved later in the calving season. Moreover, in her lifetime, heifers that calved during the first 21-day period of their first calving season weaned approximately one more calf compared (210-316 kg) to heifers that calved later in the calving season. Therefore, developing heifers so that they conceive early in the breeding season and subsequently calve early in the calving season is critical for heifer longevity in the herd as well as the performance of her progeny in subsequent generations.

\section{Acknowledgments}

This study was funded by the Saskatchewan Agriculture Development Fund (ADF\#20150160) and the Canada-Saskatchewan Growing Forward 2 Bi-Lateral agreement. The authors thank the staffs of the Western Beef Development Centre for their careful husbandry and data collection over the decades. Amartuvshin Daalkhaijav helped in data preparation.

\section{References}

Alberta Agriculture and Forestry. (2016). AgriProfit\$ Multi-year economic, productive and financial performance of Alberta cow/calf operations. Retrieved from http://www1.agric.gov.ab.ca/\$department/deptdocs.nsf/all/econ8479.

Bridges, G. A. (2013). Replacement female strategies. Proceedings of the 2013 Driftless Region Beef Conference, 19-26. Dubuque, Iowa. Retrieved from http://www.iowabeefcenter.org/proceedings/DriftlessConference2013.pdf

Burris, M. J., \& Priode, B. M. (1958). Effect of calving date on subsequent calving performance. Journal of Animal Science, 17, 527-533. https://doi.org/10.2527/jas1958.173527x

Canadian Council on Animal Care. (2009). CCAC guidelines on: the care and use of farm animals in research, teaching and testing. CCAC, Ottawa, Canada. Retrieved from http://www.ccac.ca/Documents/Standards/Guidelines/Farm_Animals.pdf

CANFAX. (2017). Canfax 2017 Annual Report. Calgary, AB. Canada. pp. 34. Retrieved from http://www.canfax.ca/SampleReports.aspx.

Cushman, R. A., Kill, L. K., Funston, R. N., Mousel, E. M., \& Perry, G. A. (2013). Heifer calving date positively influences calf weaning weights through six parturitions. Journal of Animal Science, 91, 4486-4491. 
https://doi.org/10.2527/jas.2013-6465

Damiran, D., Lardner, H. A., Larson, K., \& McKinnon, J. J. (2016). Effects of supplementing spring-calving beef cows grazing barley crop residue with canola meal and wheat-based dry distillers' grains with solubles on performance, reproductive efficiency, and system cost. Proffesional Animal Scientist, 32, 400-410. http://dx.doi.org/10.15232/pas.2015-01479

Damiran, D., Penner, G. B., Larson, K., \& Lardner, H. A. (2018). Use of residual feed intake as a selection criterion on the performance and economics for replacement beef heifers. Proffesional Animal Scientist, 34, 156-166. https://doi.org/10.15232/pas.2017-01635

Funston, R. N., Musgrave, J. A., Meyer, T. L., \& Larson, D. M. (2012). Effect of calving period on heifer progeny. Nebraska Beef Cattle Report. pp. 18-19. Retrieved from https://digitalcommons.unl.edu/cgi/viewcontent.cgi?article=1667\&context=animalscinbcr

Krause, A. D., Lardner, H. A., McKinnon, J. J., Hendrick, S., Larson, K., \& Damiran, D. (2013). Comparison of grazing oat and pea crop residue versus feeding grass-legume hay on beef-cow performance, reproductive efficiency, and system cost. Proffesional Animal Scientist, 29, 535-545. http://dx.doi.org/10.15232/S1080-7446(15)30275-8

Lardner, H. A., Damiran, D., Hendrick, S., Larson, K., \& Funston. R. (2014). Effect of development system on growth and reproductive performance of beef heifers. Journal of Animal Science, 92, 3116-3126. https://doi.org/10.2527/jas.2013-7410

Lesmeister, J. L., Burfening, P. J., \& Blackwell, R. L. (1973). Date of first calving in beef cows and subsequent calf production. Journal of Animal Science, 36, 1-6. https://doi.org/10.2527/jas1973.3611

McMillan, S., Penner, G. B., McKinnon, J. J., Larson, K., Añez-Osuna, F., Damiran, D., \& Lardner, H. A. (2018). Use of extensive winter feeding systems for backgrounding beef calves and the effect on finishing. Proffesional Animal Scientist, 34, 19-31. https://doi.org/10.15232/pas.2017-01614

Melton, B. E. (1995). Conception to consumption: The economics of genetic improvement. Proceedings of the Beef Improvement Federation Annual Meeting and Research Symposium, 24, 40-47.

Morrow, D. L., \& J. S. Brinks, J. S. (1968). The effect of season of birth of calf on weaning weights and cow production. 19th Annual Beef Cattle Improvement Day and Auction Report. San Juan Branch Experiment Station, Colorado State University General Series 869.

Patterson, D. J., Corah, L. R., Brethour, J. R., Higgins, J. J., Kiracofe, G. H., \& Stevenson, J. S. (1992). Evaluation of reproductive traits in Bos taurus and Bos indicus crossbred heifers: Relationship of age at puberty to length of the postpartum interval to estrus. Journal of Animal Science, 70, 1994-1999. https://doi.org/10.2527/1992.7071994x

Roberts, A. J., Spencer, LeFever, D. G., \& Wiltbank, J. N. (1970). Increasing reproductive efficiency in a cow herd. Journal of Animal Science, 30, 1032.

SAS, (2003). User's Guide: Statistics (8th ed.), SAS Inst., Inc., Cary, NC.

Sprott, L. R. (2000). Reproductive performance in replacement heifers has long-term consequences on the cow herd. Texas A\&M Publication, ASWeb-100. Retrieved from http://aglifesciences.tamu.edu/animalscience/wp-content/uploads/sites/14/2012/04/beef-reproductive-perfor mance.pdf

Wiltbank, J. N. (1970). Research needs in cattle reproduction. Journal of Animal Science, 31, 755-762. https://doi.org/10.2527/jas1970.314755x

\section{Copyrights}

Copyright for this article is retained by the author(s), with first publication rights granted to the journal.

This is an open-access article distributed under the terms and conditions of the Creative Commons Attribution license (http://creativecommons.org/licenses/by/3.0/). 